\title{
THE ROLE OF MULTIPLE REGRESSION ANALYSIS IN PREDICTION OF INSULIN RESISTANCE IN OVERWEIGHT AND OBESE CHILDREN
}

\author{
Halyna PAVLYSHYN ${ }^{1}$, Kateryna KOZAK ${ }^{1 凶}$ \\ ${ }^{1}$ Department of Pediatrics № 2, I. Horbachevsky Ternopil National Medical University, Ternopil, Ukraine \\ Received 24 Apr 2019, Accepted 17 June 2019 \\ htpp://doi.org/10.31688/ABMU.2019.54.3.18
}

\section{Abstract}

Introduction. Overweight and obesity is a global epidemic among children of all age groups. Obese children are at increased risk of insulin resistance, cardiovascular disease (including arterial hypertension), as well as bone fractures and psychological problems. In this regard, insulin resistance has become one of the most serious health concerns in overweight and obese children.

The objective of the study was to investigate the specifics for carbohydrate metabolism in overweight and obese children, to identify the key factors for insulin resistance and to develop a regression analysis-based prognostic model to predict its occurrence.

Material and methods. In 90 obese and 20 overweight children aged between 10-17 years, anthropometric measurements, history data collection and laboratory investigations were performed. Multiple regression analysis has been used to develop a mathematical model for prediction of insulin resistance.

Results. Such variables as weight, body mass index, waist and hip circumferences, abdominal type obesity, family history, duration of breastfeeding (if any), birth weight, sedentary lifestyle, leptin and adiponectin levels and dyslipidemia were closely related to fasting glucose levels and insulin/insulin resistance indices.
\end{abstract}

\section{Résumé}

Le rôle de l'analyse de régression multiple dans la prédiction de la résistance à l'insuline chez les enfants avec surpoids et obèses

Introduction. L'excédent de poids et l'obésité constituent une épidémie à l'échelle mondiale chez les enfants de tous les groupes d'âge. Les enfants obèses présentent un risque accru de résistance à l'insuline, de maladies cardiovasculaires (y compris l'hypertension), de fractures osseuses et de problèmes psychologiques. À cet égard, la résistance à l'insuline est devenue l'un des problèmes de santé les plus graves chez les enfants avec surpoids et obèses.

L'objectif de l'étude était d'étudier les traits spécifiques du métabolisme des glucides chez les enfants avec surpoids et obèses, d'identifier les facteurs clés de la résistance à l'insuline et de développer un modèle pronostique basé sur une analyse de régression pour prédire son occurrence.

Matériels et méthodes. Des mesures anthropométriques, la collecte de données sur l'histoire et des examens de laboratoire ont été effectués chez 90 enfants obèses et 20 enfants avec surpoids de 10 à 17 ans. L'analyse de régression multiple a été utilisée pour $\bowtie$ Address for correspondence:
Kateryna KOZAK

Department of Pediatrics № 2, I. Horbachevsky Ternopil National Medical University, Ternopil, Ukraine

Address: Maidan Voli, 1, Ternopil, 46001, Ukraine

E-mail: katerynakozak11@gmail.com; Phone +380971340370 
Conclusions. Abdominal obesity, male gender, family history of abnormal carbohydrate metabolism, insulin levels, duration of breastfeeding and plasma leptin levels have been defined as main predictors of insulin resistance in overweight and obese children and were included in regression equation for the index of insulin resistance using the method of multiple regression analysis.

Keywords: insulin resistance, obesity, children, multiple regression analysis.

\author{
Abbreviations: \\ IR - insulin resistance; WC - waist circumference; \\ $\mathrm{HC}$ - hip circumference; $\mathrm{W} / \mathrm{H}$ ratio - waist-hip ratio; \\ BMI - body mass index; \\ AO - abdominal obesity; HOMA-IR - insulin resis- \\ tance index HOMA (Homeostasis model assessment); \\ $\mathrm{CI}$ - confidence interval.
}

\section{INTRODUCTION}

Global prevalence of obesity has increased dramatically over the recent decades. Furthermore, predictions have been made that the trend will continue, the majority of global adult population will be either overweight or obese by $2030^{1}$. In Europe, the incidence of obesity is 20\% in Switzerland, Bulgaria, Italy, France and Spain, 30\% in Germany, Finland, the UK and $40 \%$ in Romania ${ }^{2}$.

Overweight and obesity is a global epidemic among children of all age groups. Approximately 216 million children throughout the world are overweight, moreover, one in six children is overweight or obese according to the report of Organization for Economic Co-operation and Development in $2014^{3}$. The prevalence of obesity has rapidly increased in Europe - 41 million of children were overweight or obese in $2016^{3}$. In Ukraine, excessive weight has been found in $12 \%$ of children aged 7 to 17 years; among them, about $10 \%$ are obese ${ }^{4}$.

Obese children are at least twice as likely to become obese as adults and have an increased risk of cancer, premature death and disability in their adulthood. In addition to long-term risks, obese children are at increased risk for fractures, hypertension, cardiovascular disease and psychological problems ${ }^{5-6}$.

Given the current increase in prevalence of obesity, the study of insulin resistance (IR) has become an important area of research in public health. développer un modèle mathématique permettant de prédire la résistance à l'insuline.

Résultats. Des variables telles que le poids, l'indice de masse corporelle, la circonférence de la taille et des hanches, l'obésité de type abdominal, les antécédents familiaux, la durée de l'allaitement (le cas échéant), le poids à la naissance, le style de vie sédentaire, les niveaux de leptine et d'adiponectine et la dyslipidémie étaient étroitement liés aux taux de glucose à jeun et à l'insuline / indices de résistance à l'insuline.

Conclusions. L'obésité abdominale, le sexe masculin, les antécédents familiaux du métabolisme anormal des glucides, les taux d'insuline, la durée de l'allaitement et les taux plasmatiques de leptine ont été définis comme les principaux prédicteurs de la résistance à l'insuline chez les enfants obèses et avec surpoids et ont été inclus dans l'équation de régression pour l'indice de résistance à l'insuline en utilisant la méthode de l'analyse de régression multiple.

Mots-clés: résistance à l'insuline, obésité, enfants, analyse de régression multiple.

Although genetically determined, insulin resistance may be contributed to by a variety of exogenous factors such as obesity, race and ethnicity, gender, perinatal factors, puberty, physical inactivity, excessive consumption of foods rich in carbohydrates and fats and stress?

In spite of the fact that insulin resistance has been studied for a long time, no statistical analyses, such as multiple regression analysis, have been performed.

THE OBJECTIVE OF THE STUdy was to determine the peculiarities of carbohydrate metabolism in overweight or obese children, to determine the key factors of insulin resistance and to develop an equation for mathematical calculation of insulin resistance index, which will be helpful to general care practitioners and pediatricians.

\section{Material AND MEthods}

\section{Study design and patients}

A population of 110 children $10-17$ years of age ( 90 with obesity and 20 overweight) has been assessed. All study subjects and their parents gave their written informed consent for study assessments and for study results to be published in scientific literature. The study has been approved by Bioethics Commission of I. Horbachevsky Ternopil State Medical University (protocol number 24 (27.08.2014). 


\section{Collection of clinical, anthropometric and labo- ratory data}

Anthropometric measurements, such as body weight in kilograms, height in meters, waist circumference (WC) and hip circumference (HC) in centimeters, waist-hip ratio (W/H ratio) and body mass index (BMI) were conducted for all children. The diagnosis of overweight was made when BMI was equal to or above the age- and sex-matching $85^{\text {th }}$ percentile, but below the respective $95^{\text {th }}$ percentile. The patients were diagnosed as obese when their BMI was equal to or above the $95^{\text {th }}$ percentile. The diagnosis of normal body weight was made when BMI ranged from the $5^{\text {th }}$ percentile to below $85^{\text {th }}$ percentile ${ }^{8}$. Abdominal obesity (AO) was diagnosed in children $10-16$ years of age with a WC equal to or above the age- and sex-matching $90^{\text {th }}$ percentile and in children older than 16 years with a WC equal to or more than 94 centimeters for boys and equal to or more than 80 centimeters for girls?.

History data included information about birth weight, availability and duration of breastfeeding, family history and sedentary behaviors (duration of television watching and working/playing on the computer during the day).

Levels of fasting glucose, insulin in blood, values of HOMA-IR index (homeostasis model assessment) and the results of oral glucose tolerance test were subject to analysis as parameters of carbohydrate metabolism. Serum levels of insulin and adipocytokines (leptin and adiponectin) were assayed with the enzyme immunoassay method. According to instructions included with test kits ("DRG Insulin ELISA», Germany; «DRG Leptin (Sandwich) ELISA», Germany; "AssayMax Human Adiponectin ELISA Kit», USA) normal level of insulin was below 25 microUnits $/ \mathrm{mL}$ $(\mu \mathrm{U} / \mathrm{mL})$; normal values of leptin were 2.05-5.63 ng/ $\mathrm{ml}$ for boys and 3.63-11.09 ng/ml for girls; normal adiponectin level was $8300-13900 \mathrm{ng} / \mathrm{mL}$.

Insulin resistance was diagnosed after calculation of the HOMA-IR index from the following equation: HOMA-IR = (basal fasting insulin level $($ microUnits $/ \mathrm{ml}) \times$ fasting glucose $(\mathrm{mmol} / \mathrm{l})) / 22.5$. According to literature, the conclusion of insulin resistance was made when the level of HOMA-IR was higher than 3.16 units $^{10}$.

Serum lipid profiles were assessed in all participants. The diagnosis of dyslipidemia was made when the following criteria were met: total cholesterol (TC) equal to or above $5.18 \mathrm{mmol} / \mathrm{L}$, low-density lipoprotein cholesterol (LDL-C) equal to or above 3.37 $\mathrm{mmol} / \mathrm{L}$, non-high-density lipoprotein cholesterol (Non-HDL-C) equal to $3.76 \mathrm{mmol} / \mathrm{L}$ or higher, triglycerides (TG) equal to or above $1.47 \mathrm{mmol} / \mathrm{L}$ and high-density lipoprotein cholesterol (HDL-C) below
$1.04 \mathrm{mmol} / \mathrm{L}$. Non-HDL-C values were calculated as TC- HDL-C ${ }^{11}$.

\section{Statistical analysis}

Statistical analysis was performed using the methods of variation statistics and computer software. Histograms, Kolmogorov-Smirnov test and Shapiro-Wilk's tests were used to assess the normality of variables. Based on the obtained results the parametric statistical methods were employed. Comparison of two independent samples was performed using Student t-test. The differences were considered statistically significant at $\mathrm{p}<0.05$. Pearson correlation coefficient was used to assess the degree of interdependence between the variables. Based on correlation matrices, multiple regression analysis was performed.

\section{Results}

Male gender was significantly more prevalent in overweight or obese children (77.3\% [95\% CI 69.4; 85.1]) than female gender $22.7 \%$ (95\% CI $14.9 ; 30.6)$ $(\mathrm{p}<0.001)$. Overweight and obesity are more prevalent in boys more than 16 years of age $(59.1 \%$ [95\% CI 49.9; 68.3]) and in girls 12 to 16 years of age $(17.3 \%$ [95\% CI $10.2 ; 24.3])$. Abdominal type obesity was diagnosed in $81.8 \%$ cases ( 90 children) (95\% CI 74.6; 89.0). There were no gender-specific differences in abdominal obesity ( $\mathrm{p}>0.05$ ); it was found in $83.5 \%$ boys $(95 \%$ CI 75.6 ; 91.4 ) and in $76 \%$ girls (95\% CI 59.3; 92.7).

The average fasting glucose level was $5.21 \pm 0.96$ $\mathrm{mmol} / \mathrm{L}$. Hyperglycemia was found in $35.6 \%$ of all cases $(95 \%$ CI $22.3 ; 39.5)$. The average insulin level was $20.35 \pm 8.93 \mu \mathrm{U} / \mathrm{mL}$. Hyperinsulinemia was diagnosed in 37 persons (33.6\% [95\% CI 24.8; 42.5]). The average HOMA-IR index was $4.67 \pm 2.30$ units. Insulin resistance was found in $69.1 \%$ (95\% CI $60.5 ; 77.7)$ of all pediatric subjects in the study. Impaired fasting glucose was found in $7.3 \%$ participants (95\% CI 3.2; 11.4), that is, in 7 boys and in 1 girl; impaired glucose tolerance was found in 3 male subjects $(2.7 \%$ [95\% CI 0.2; 5.3]).

No gender-specific differences of glucose levels, insulin levels and HOMA-IR index were found: glucose level was $5.22 \pm 0.96 \mathrm{mmol} / \mathrm{L}$ in boys and $4.82 \pm 0.77 \mathrm{mmol} / \mathrm{L}$ in girls; insulin level was $20.83 \pm 8.85 \mu \mathrm{U} / \mathrm{mL}$ in boys and $18.70 \pm 9.18 \mu \mathrm{U} / \mathrm{mL}$ in girls; HOMA-IR index was $4.83 \pm 2.27$ units in boys and $4.10 \pm 2.38$ units in girls ( $p>0.05$ ). Hyperglycemia was detected in $36.5 \%$ of boys $(95 \%$ CI $26.2 ; 46.7)$ and in $12.0 \%$ of girls $(95 \%$ CI $0.7 ; 24.7)(\mathrm{p}<0.03)$. Hyperinsulinemia was found in $36.5 \%$ of male subjects $(95 \%$ CI $26.2 ; 46.7)$ and in $24.0 \%$ of female subjects $(95 \%$ CI $7.3 ; 40.7)(p>0.05)$. Insulin resistance was more common in male subjects: $74.1 \%$ of cases 
Table 1. Matrices for correlations between variables of carbohydrate metabolism and anthropometric parameters

\begin{tabular}{cccccc}
\hline Parameter & Weight & BMI & WC & HC & W/H ratio \\
\hline \multirow{2}{*}{ Glucose } & $\mathrm{r}=0.07$ & $\mathrm{r}=0.05$ & $\mathrm{r}=0.03$ & $\mathrm{r}=0.12$ & $\mathrm{r}=0.11$ \\
\cline { 2 - 5 } & $\mathrm{p}=0.48$ & $\mathrm{p}=0.57$ & $\mathrm{p}=0.80$ & $\mathrm{p}=0.22$ & $\mathrm{p}=0.27$ \\
\hline \multirow{2}{*}{ Insulin } & $\mathrm{r}=0.21^{*}$ & $\mathrm{r}=0.24^{*}$ & $\mathrm{r}=0.25^{*}$ & $\mathrm{r}=0.26^{*}$ & $\mathrm{r}=0.14$ \\
\cline { 2 - 5 } & $\mathrm{p}=0.02$ & $\mathrm{p}=0.01$ & $\mathrm{p}=0.01$ & $\mathrm{p}=0.01$ & $\mathrm{p}=0.15$ \\
\hline \multirow{2}{*}{ HOMA-IR } & $\mathrm{r}=0.26^{*}$ & $\mathrm{r}=0.25^{*}$ & $\mathrm{r}=0.25^{*}$ & $\mathrm{r}=0.25^{*}$ & $\mathrm{r}=0.14$ \\
\cline { 2 - 5 } & $\mathrm{p}=0.01$ & $\mathrm{p}=0.01$ & $\mathrm{p}=0.01$ & $\mathrm{p}=0.01$ & $\mathrm{p}=0.13$ \\
\hline
\end{tabular}

Note. ${ }^{*}=$ the correlation is evaluated as significant.

Table 2. Levels of glucose, insulin and HOMA-IR depending on abdominal obesity status

\begin{tabular}{ccc}
\hline Indices & Children with $\mathrm{AO}(\mathrm{n}=90)$ & Children without $\mathrm{AO}(\mathrm{n}=20)$ \\
\hline Glucose, $\mathrm{mmol} / \mathrm{l}$ & $5.09 \pm 0.89$ & $5.29 \pm 1.12$ \\
\hline Insulin, $\mu \mathrm{U} / \mathrm{ml}$ & $21.75 \pm 8.93^{*}$ & $14.02 \pm 5.67$ \\
\hline HOMA-IR index, units & $4.97 \pm 2.34^{*}$ & $3.32 \pm 1.53$ \\
\hline Note. ${ }^{*}$ - the $p$ coefficient for the T-test for independent samples: $\mathrm{p}<0.05$. & \\
\hline
\end{tabular}

Table 3. Parameters of carbohydrate metabolism stratified by anamnestic data

\begin{tabular}{|c|c|c|c|}
\hline \multirow{2}{*}{ Anamnestic data } & \multicolumn{3}{|c|}{ Indices } \\
\hline & Glucose, $\mathrm{mmol} / \mathrm{L}$ & Insulin, $\mu \mathrm{U} / \mathrm{mL}$ & HOMA-IR index, units \\
\hline \multicolumn{4}{|c|}{ Family history } \\
\hline $\begin{array}{l}\text { Children with family history of } \\
\text { diabetes }(n=12)\end{array}$ & $5.96 \pm 0.68^{*}$ & $20.15 \pm 10.05$ & $5.84 \pm 2.78$ \\
\hline $\begin{array}{l}\text { Children without family history of } \\
\text { diabetes }(n=98)\end{array}$ & $5.03 \pm 0.91$ & $21.93 \pm 8.82$ & $4.53 \pm 2.21$ \\
\hline \multicolumn{4}{|c|}{ Breastfeeding in infancy } \\
\hline $\begin{array}{l}\text { Children who received breast milk } \\
\text { in infancy }(n=89)\end{array}$ & $5.03 \pm 0.83^{*}$ & $19.48 \pm 8.58^{*}$ & $4.35 \pm 2.03^{*}$ \\
\hline $\begin{array}{l}\text { Children who received formula in } \\
\text { infancy }(\mathrm{n}=21)\end{array}$ & $5.55 \pm 1.20$ & $24.00 \pm 9.67$ & $6.00 \pm 2.90$ \\
\hline \multicolumn{4}{|c|}{ Birth weight } \\
\hline $\begin{array}{l}\text { Children with small for gestational } \\
\text { age birth weight }(n=4)\end{array}$ & $5.55 \pm 1.14$ & $12.73 \pm 2.88$ & $3.12 \pm 0.84$ \\
\hline $\begin{array}{l}\text { Children with normal birth weight } \\
\qquad(\mathrm{n}=94)\end{array}$ & $5.06 \pm 0.95$ & $20.73 \pm 8.93$ & $4.69 \pm 2.28$ \\
\hline $\begin{array}{l}\text { Children with large for gestational } \\
\text { age birth weight }(\mathrm{n}=12)\end{array}$ & $5.53 \pm 0.60$ & $19.87 \pm 9.53$ & $5.01 \pm 2.71$ \\
\hline
\end{tabular}

(95\% CI 64.8; 83.4), while in female subjects it was found in $52.0 \%(95 \%$ CI 32.4; 71.6) of cases ( $p<0.04)$.

The relationships between carbohydrate metabolism and anthropometric parameters have been evaluated in a correlation analysis (Table 1).

It was found that the levels of insulin and insulin resistance index were significantly higher in children with central obesity (Table 2). Hyperglycemia was found in $32.2 \%(95 \%$ CI $20.5 ; 39.5)$ of patients with abdominal obesity versus 25\% (95\% CI 6.0; 44.0 ) of subjects in the group without abdominal obesity ( $p>0.05$ for the difference). AO contributed to significant differences in insulin levels: in the group with central type obesity, hyperinsulinemia was found in $40.0 \%$ of subjects (95\% CI $29.9 ; 50.1$ ) and only in $5.0 \%$ of subjects in the group without $\mathrm{AO}$ $(95 \%$ CI $4.6 ; 14.6)(p<0.01)$. Insulin resistance rates were significantly higher in AO subjects: $74.4 \%$ (95\% CI $65.4 ; 83.5)$ versus $45.0 \%(95 \%$ CI $23.2 ; 66.8)$ in subjects without $\mathrm{AO}(\mathrm{p}<0.02)$.

Family history involves obtaining data about type 1 and type 2 diabetes in members of subjects' 
Table 4. Correlation analysis for parameters of carbohydrate metabolism and leptin and adiponectin levels

\begin{tabular}{ccccc}
\hline \multirow{2}{*}{ Indices } & \multicolumn{2}{c}{ Leptin } & \multicolumn{2}{c}{ Adiponectin } \\
\cline { 2 - 5 } & $\begin{array}{c}\text { The correlation coef- } \\
\text { ficient, } r\end{array}$ & p-values, $p$ & $\begin{array}{c}\text { The correlation coef- } \\
\text { ficient, } r\end{array}$ & $p$-values, $p$ \\
\hline Glucose, $\mathrm{mmol} / \mathrm{L}$ & 0.02 & $\mathrm{p}>0.05$ & -0.06 & $\mathrm{p}>0.05$ \\
\hline Insulin, $\mu \mathrm{U} / \mathrm{mL}$ & $0.27^{*}$ & $\mathrm{p}<0.02$ & $-0.32^{*}$ & $\mathrm{p}<0.01$ \\
\hline HOMA-IR index, units & $0.28^{*}$ & $\mathrm{p}<0.01$ & $-0.29^{*}$ & $\mathrm{p}<0.01$ \\
\hline Note. ${ }^{*}=$ the value is statistically significant. & & & \\
\hline
\end{tabular}

Table 5. Levels of glucose, insulin and HOMA-IR based on lipid status

\begin{tabular}{ccc}
\hline Indices & $\begin{array}{c}\text { Group of children without dyslipidemia } \\
(n=66)\end{array}$ & Group of children with dyslipidemia $(n=44)$ \\
\hline Glucose, $\mathrm{mmol} / \mathrm{L}$ & $4.95 \pm 0.85$ & $5.40 \pm 0.98^{*}$ \\
\hline Insulin, $\mu \mathrm{U} / \mathrm{mL}$ & $18.97 \pm 8.90$ & $22.41 \pm 8.67^{*}$ \\
\hline HOMA-IR index, units & $4.23 \pm 2.30$ & $5.33 \pm 2.16^{*}$ \\
\hline Note. ${ }^{*}=$ p coefficient for the T-test for independent samples, $\mathrm{p}<0.05$. & \\
\hline
\end{tabular}

families (relatives of the first and the second degree). History of impaired carbohydrate metabolism was positive in $10.9 \%$ (95\% CI $5.1 ; 16.7)$ of cases. In children with positive family history, glucose levels were found to be significantly higher than in children without family history of diabetes $(p<0.001)$ (Table 3).

Breastfeeding is another potential factor to impact carbohydrate metabolism. Among study subjects, $80.9 \%$ (95\% CI 73.6; 88.3) (89 subjects) were breastfed in early childhood. The duration of breastfeeding during infancy was $4.33 \pm 3.83$ months. The analysis has demonstrated that children with access to breast milk in their infancy had significantly lower glucose and insulin levels and lower HOMA-IR indices at 10-17 years of age compared to their formula-fed peers $(p<0.05)$ (Table 3). The results of the study have demonstrated a reverse correlation to exist between blood glucose levels and duration of breastfeeding $(\mathrm{r}=-0.23$, $\mathrm{p}<0.02$ ).

Our study has not found any significant differences in levels of blood glucose, insulin and insulin resistance index between children born with normal, small (less than 2500 grams) and large for gestational age body weight (4000 g) (p>0.05) (Table 3). Despite the absence of birth weight-specific differences in markers of carbohydrate metabolism at the age of 10-17 years, the study has found a correlation between birth weight and insulin level $(r=0.27, p<0.01)$ and HOMA-IR index $(r=0.29, \mathrm{p}<0.01)$.

The average time of watching television and/ or playing/working on the computer was $2.98 \pm 0.98$ hours. Insulin levels and insulin resistance indices were found to increase with the time of TV watching or computer work/play. This fact can be proven by a direct correlation between sedentary lifestyle and the levels of insulin $(r=0.22, p<0.03)$ and HOMA-IR index $(r=0.23, p<0.02)$. At the same time, we have not found any significant correlations between the time of passive rest and fasting glucose levels $(\mathrm{r}=0.03$, $\mathrm{p}>0.05$ ).

The average level of leptin in the blood of children with overweight and obesity was $51.29 \pm 32.65$ $\mathrm{ng} / \mathrm{mL}$. The level of adiponectin was $2186.36 \pm 306.32$ $\mathrm{ng} / \mathrm{mL}$. We have found a relationship to exist between the parameters of carbohydrate metabolism and serum levels of leptin and adiponectin (Table 4).

Dyslipidemia was diagnosed in $40.0 \%$ (95\% CI 32.3 ; 47.7) of overweight or obese children. Taking into account that dyslipidemia and insulin resistance are closely interrelated, analysis of carbohydrate metabolism has been performed based on presence vs. absence of lipid disorders. The levels of fasting glucose, insulin and HOMA-IR index were significantly higher in the group of children with previously diagnosed dyslipidemia (Table 5).

The results of the study have shown that multiple factors were closely connected with the parameters of carbohydrate metabolism. Therefore, in multiple regression analysis, insulin resistance index (HOMA-IR) was used as a dependent variable. Anthropometric parameters (body weight, BMI, WC, $\mathrm{HC}$ and $\mathrm{W} / \mathrm{H}$ ratio), presence/absence of abdominal obesity, family history of diabetes, birth weight, availability and duration of breastfeeding, time spent at a $\mathrm{TV} /$ computer, dyslipidemia and levels of leptin and adiponectin were all used as independent variables.

Based on analysis of correlation matrices, independent variables with strong pairwise correlations have been identified. Less significant variables were excluded from further analysis. As a result of 
Table 6. Results of multiple regression analysis

\begin{tabular}{|c|c|c|c|c|c|c|}
\hline \multicolumn{7}{|c|}{$\begin{array}{c}\text { Regression Summary for Dependent Variable: HOMA-IR } R=0.95 R^{2}=0.90 \\
\text { Adjusted } R^{2}=0.89 F(6,81)=122.62 p\end{array}$} \\
\hline & Beta & Std.Err. & $B$ & Std.Err. & $t$ & p-value \\
\hline Intercept & & & 0.69 & 0.68 & 1.01 & 0.32 \\
\hline Leptin level & 0.11 & 0.05 & 0.01 & 0.01 & 2.38 & 0.02 \\
\hline Family history & -0.09 & 0.04 & -0.66 & 0.27 & -2.42 & 0.02 \\
\hline Duration of breastfeeding & -0.12 & 0.04 & -0.08 & 0.02 & -3.49 & $<0.001$ \\
\hline Gender & -0.08 & 0.04 & -0.43 & 0.25 & -1.73 & 0.04 \\
\hline Abdominal obesity & 0.10 & 0.04 & 0.60 & 0.24 & 2.46 & 0.02 \\
\hline Insulin level & 0.92 & 0.04 & 0.25 & 0.01 & 23.63 & $<0.001$ \\
\hline
\end{tabular}

completed regression analysis (see Table 6), we have obtained a regression equation for a deeper understanding of pathogenesis of insulin resistance:

HOMA-IR index $=0.69+0.60 \mathrm{AO}+(-0.43)$ gender $+(-0.66)$ family history +0.25 insulin level + $(-0.08)$ duration of breastfeeding +0.01 leptin

For some variables in this equation, we have used numeric codes, i.e. absence of abdominal obesity $=1$, presence of abdominal obesity $=2$; male gender $=1$, female gender $=2$; positive family history of diabetes $=1$, absence of family history of diabetes $=$ 2. The levels of insulin and leptin and breastfeeding duration were presented as their absolute numerical values.

The coefficient of determination, $\mathrm{R}^{2}$ equals 0.90 , which means that $90 \%$ of insulin resistance cases in overweight and obese children aged 10-17 years could be explained by 6 different predictors (independent variables).

\section{Discussion}

Although IR is a thoroughly studied polyetiological condition, the results of our research work have identified the most significant contributing factors of IR in overweight and obese children 10-17 years of age, i.e. abdominal obesity, gender, anamnestic data (family history of diabetes and duration of breastfeeding) and laboratory findings (insulin and leptin levels). Our research has stressed the importance of a multifaceted approach to IR assessment in childhood and provided new opportunities for its diagnosis.

First, we have confirmed the opinion of other authors that abdominal type of obesity is a prerequisite for $\mathrm{IR}^{12}$. The relationship between abdominal obesity and IR is attributable to the so-called „portal theory". The presence of free fatty acids in the blood, resulting from a higher lipolytic activity in visceral fat, impairs binding of insulin to specific receptors and causes dysfunction of GLUT-4 glucose transporters. In addition to that, free fatty acids reduce capture of glucose by smooth muscle cells, increase triglyceride synthesis and stimulate hepatic gluconeogenesis $^{13-15}$.

The fact that IR is more prevalent in boys is attributable to the influence of sex steroids on adipose tissue and the different sensitivity of adipocytes to lipolytic stimuli of sex hormones. Estrogens may have beneficial effects on insulin sensitivity via a number of possible mechanisms: these may involve direct effects on insulin and glucose homeostasis, involvement in adipose tissue metabolism and body composition, or effects on proinflammatory markers ${ }^{16}$. Moreover, in men, complete lack of synthesis or activity of estrogens is associated with IR. Moran et al found that during adolescence in males, IR was significantly increased despite significant decreases in adiposity, whereas in females, body fat significantly increased, but IR did not significantly change ${ }^{17}$. Increasing IR in boys occurred independently of increasing lean mass and decreasing fat mass, possibly due to the relative decrease in estrogen in males compared with females. On the other hand, testosterone was found to reduce the concentration of adiponectin and decreased levels of adiponectin were found to be possibly associated with increased IR ${ }^{18}$.

Breastfeeding in infancy was the next factor that has been shown in the equation. This can be attributed to the fact that breast milk contains adipocytokines (leptin and adiponectin), which take part in regulation of carbohydrate metabolism ${ }^{19}$. Other authors have established that 6 months of breastfeeding significantly reduced the risk of IR, obesity and metabolic syndrome later in childhood and adulthood ${ }^{20,21}$.

Heredity has a considerable role in pathogenesis of IR. This relationship is the result of mutation and expression of genes encoding insulin, proinsulin, tyrosine kinase of insulin receptor and its substrate, $\alpha_{2}$-SH-glycoprotein, membrane glycoprotein PC-1, insulin mediator IRS-1, GLUT-2, GLUT-4, hexokinase II, glycogen synthetase, glucokinase. Mutations of the leptin gene, leptin receptor, proopiomelanocortin 
receptors, type 3 and type 4 melanocortin receptors, genes of lipoprotein lipase, hormone-sensitive lipase, glycogen synthase of skeletal muscle, substrate of insulin receptor type 1 and others have been identified $^{22}$.

A potential contributor to insulin resistance may include hyperleptinemia. Some authors believe that leptin is a link between adipocytes and pancreatic cells and that leptin stimulates insulin secretion in reduced sensitivity to insulin ${ }^{23}$. At the same time, there are publications showing that prolonged hyperleptinemia inhibits the expression of insulin mRNA, which may ultimately serve as a trigger of hyperglycemia and $I^{24}$. Osegbe et al (2016) have found a positive correlation between the level of leptin and the severity of IR in females with different BMI values ${ }^{25}$. Leptin may also inhibit insulin receptor signal through activation of the suppressor of cytokine signal type $3^{26}$. Nevertheless, until now the exact role of leptin in the pathogenesis of insulin resistance is still unclear.

Endothelial dysfunction is an important component of insulin resistance. Insulin regulates glucose homeostasis not only by promoting utilization of glucose in skeletal muscle and adipose tissue and by inhibiting hepatic gluconeogenesis, but also by regulating delivery of nutrients to target tissues by its effects in microvasculature ${ }^{27}$. The causes of endothelial dysfunction may include multiple factors, including hyperglycemia, hyperlipidemia, cytokine effects and free radical damage ${ }^{28,29}$.

Some independent variables (birth weight, time spent near TV or computer, dyslipidemia, adiponectin level) were not included in the regression equation during statistical analysis, but their role in pathogenesis of insulin resistance should also be taken into account.

The correlations between birth weight and insulin resistance could be explained by the theory of „metabolic programming“ during fetal development, according to which various factors that affect the fetus, may cause life-lasting changes and influence further development of metabolic disorders ${ }^{30}$.

We have found that increasing time of television watching or computer gaming/working causes hyperinsulinemia and insulin resistance. This fact has a pathogenetic substantiation, because sitting for prolonged periods of time decreases tactile stimulation of local muscles, thus leading to inhibition of GLUT4 glucose transporters and reduced capture of glucose by skeletal myocytes. The resulting hyperinsulinemia is acting as a compensatory mechanism to provide the cells with source of energy (glucose) ${ }^{31}$.

The relationship between dyslipidemia and abnormal carbohydrate metabolism is a topic for discussion, because these two processes are closely interconnected. Hepatic lipase activity was found to increase in insulin resistance; as a result, excessive amounts of free fatty acids enter the liver, increasing hepatic synthesis of triglycerides, whose metabolism includes the synthesis of low and very low density lipoproteins ${ }^{32}$.

Adiponectin reduces insulin resistance by increasing sensitivity to insulin. This could result from various effects of this adipokine. Adiponectin stimulates phosphorylation of insulin receptor and slows down gluconeogenesis by reducing the inflow of free fatty acids to the liver. In addition to that, this adipokine inhibits the expression of phosphoenolpyruvate carboxy-kinase and glucose-6-phosphatase ${ }^{33}$.

\section{Conclusions}

The results of our study have shown that the most serious factors contributing to insulin resistance in overweight and obese children 10-17 years of age include abdominal type of obesity, male gender, family history of carbohydrate disorders, duration of breastfeeding and the levels of insulin and leptin in blood. The proposed regression equation makes calculation and evaluation of insulin resistance index possible for practicing physicians and not just scientists. This method to assess insulin resistance undoubtedly takes more time; however, it provides us with a deeper understanding of this disease and increases the chances for a timely diagnosis.

\section{Compliance with Ethics Requirements:}

"The authors declare no conflict of interest regarding this article"

"The authors declare that all the procedures of this study respect the ethical standards in the Helsinki Declaration of 1975, as revised in 2008(5), as well as the national law. Informed consent was obtained from all the patients included in the study"

"No funding for this study"

\section{References}

1. Marushchak M, Krynytska I, Milevska L, Miz A, Mialiuk O. The changes of activity of effector caspase cascade components in case of alimentary obesity in rats. Bangladesh Journal of Medical Science. 2017;16(2): 252-258.

2. Żukiewicz-Sobczak W, Wróblewska P, Zwoliński J, et al. Obesity and poverty paradox in developed countries. Annals of Agricultural and Environmental Medicine. 2014;21(3): 590-594.

3. World Health Organization: Taking Action on Childhood Obesity. https://apps.who.int/iris/bitstream/handle/10665/274792/WHO-NMH-PND-ECHO-18.1-eng. pdf?ua $=1$ (accessed 05 April, 2019) 
4. Shulhai AMA, Pavlyshyn HA, Shulhai OM. Peculiarities of the prevalence and risk factors for vitamin D deficiency in overweight and obese adolescents in Ukraine. Arch Balk Med Union. 2019;54(1):57-63.

5. Kinlen D, Cody D, O'Shean D. Complications of obesity. International Journal of Medicine. 2018:437-443.

6. Krynytska I, Marushchak M, Zaets T, Savchenko I, Habor $\mathrm{H}$. Investigation of bone mineralization in patients with coronary heart disease complicated by chronic heart failure, Stage II-A. Georgian Medical News. 2017;(267):43-48.

7. Kumar S, Kelly AS. Review of childhood obesity: from epidemiology, etiology, and comorbidities to clinical assessment and treatment. Mayo Clinic Proceedings. 2017:92(2):251-265.

8. Centers for Disease Control and Prevention: Defining Childhood Obesity. https://www.cdc.gov/obesity/childhood/defining.html (2015) (Accessed 10 June 2018).

9. Alberti G, Zimmet P, Kaufman F, et al. IDF consensus definition of the metabolic syndrome in children and adolescents. International Diabetes Federation; 2007, 24 p.

10. Keskin M, Kurtoglu S, Kendirci M, Atabek ME, Yazici C. Homeostasis model assessment is more reliable than the fasting glucose/insulin ratio and quantitative insulin sensitivity check index for assessing insulin resistance among obese children and adolescents. Pediatrics. 2005;115(4):500-503.

11. Expert Panel on Integrated Guidelines for Cardiovascular Health and Risk Reduction in Children and Adolescents, \& National Heart, Lung, and Blood Institute (2011). Expert panel on integrated guidelines for cardiovascular health and risk reduction in children and adolescents: summary report. Pediatrics. 2011;128(5):S213-S256.

12. Chiarelli F, Marcovecchio ML. Insulin resistance and obesity in childhood. European Journal of Endocrinology. 2008;159(1): S67-S74.

13. Samuel VT. Mechanisms for insulin resistance: common threads and missing links. Cell. 2012;148(5):852-871.

14. Ye J. Mechanisms of insulin resistance in obesity. Frontiers of Medicine. 2013;7(1): 14-24.

15. Delarue J, Magnan C. Free fatty acids and insulin resistance. Current Opinion in Clinical Nutrition $\mathcal{E}$ Metabolic Care. 2007;10(2):142-148.

16. Greenhill C. Sex differences in insulin resistance. Nature Reviews Endocrinology. 2017;14:65.

17. Moran A, Jacobs DR Jr, Steinberger J, et al. Changes in insulin resistance and cardiovascular risk during adolescence: establishment of differential risk in males and females. Circulation. 2008;117:2361-2368.

18. Bai J, Liu Y, Niu GF, et al. Relationship between adiponectin and testosterone in patients with type 2 diabetes. Biochem Med. 2011;21(1):65-70.
19. Guardamagna O, Abello F, Cagliero P, Lughetti L. Impact of nutrition since early life on cardiovascular prevention. Italian Journal of Pediatrics. 2012;38:73-83.

20. Koletzko B, von Kries R, Monasterolo RC, et al. Infant feeding and later obesity risk. Advances in Experimental Medicine and Biology. 2009;646:15-29.

21. Twells L, Newhook LA. Can exclusive breastfeeding reduce the likelihood of childhood obesity in some regions of Canada? Canadian Journal of Public Health. 2010;101(1): 36-39.

22. Krishna VV. Metabolic syndrome: the genetic aspect. Endocrinology E⿱ Metabolic Syndrome. 2011;S1:e001.

23. Pashentseva AV, Verbovoy AF, Sharonova LA. Insulin resistance in therapeutic clinic. Obesity and Metabolism. 2017;14(2): 9-17 (in Russian).

24. Moon HS, Dalamaga M, Kim SY, et al. Leptin's role in lipo-dystrophic and non lipo-dystrophic insulin-resistant and diabetic individuals. Endocrine Reviews. 2013;34(3): 377-412.

25. Osegbe I, Okpara H, Azinge E. Relationship between serum leptin and insulin resistance among obese Nigerian women. Annals of African Medicine. 2016;15(1): 14.

26. D'souza AM, Neumann UH, Glavas MM, Kieffer TJ. The glucoregulatory actions of leptin. Molecular metabolism. 2017;6(9):1052-1065.

27. Muniyappa R, Sowers JR. Role of insulin resistance in endothelial dysfunction. Reviews in Endocrine $\mathcal{E}$ Metabolic Disorders. 2013;14(1):5-12.

28. Guzyk MM, Dyakun KO, Yanytska LV, et al. Inhibitors of Poly(ADP-Ribose)Polymerase-1 as agents providing correction of brain dysfunctions induced by experimental diabetes. Neurophysiology. 2017;49(3):183-193.

29. Janus A, Szahidewicz-Krupska E, Mazur G, Doroszko A. Insulin resistance and endothelial dysfunction constitute a common therapeutic target in cardiometabolic Disorders. Mediators of Inflammation. 2016;Vol. 2016, Article ID 3634948.

30. Marciniak A, Patro-Małysza J, Kimber-Trojnar Ż, Marciniak B, Oleszczuk J, Leszczyńska-Gorzelak B. Fetal programming of the metabolic syndrome. Taiwanese Journal of Obstetrics $\mathcal{E}^{2}$ Gynecology. 2017; 56(2):133-138.

31. Thorp AA, Genevieve NH, Owen N, et al. Deleterious associations of sitting time and television viewing time with cardiometabolic risk biomarkers. Diabetes Care. 2010;33(2):327-334.

32. Ginsberg HN, Zhang YL, Hernandez-Ono A. Metabolic syndrome: focus on dyslipidemia. Obesity. 2006;14(1):41-49.

33. Dridia S, Taouis M. Adiponectin and energy homeostasis: consensus and controversy. Journal of Nutritional Biochemistry. 2009;20(11): 831-839. 